\title{
Entrepreneurial Intention of Two Patterns of Planned Behaviour and Alertness: Empirical Evidence in China
}

\author{
Hong Lu ${ }^{12}$, Jiafure Wang ${ }^{3}$
}

Received: April 19, 2018. Revised: April 30, 2018. Accepted: May 5, 2018.

\begin{abstract}
Researches based on the pattern of planned behavior holds that the three variables of entrepreneurial attitudes, subjective norms, and perceived behavior control influence each other and influence entrepreneurial intentions respectively. However, there are also different, even conflicting research conclusions that continue to emerge. Researches based on the pattern of alertness, believe that profit opportunities and individuals' pursuit to truth are the driving forces. Many scholars have demonstrated the impact of individual entrepreneurial alertness on entrepreneurial intentions. However, as an exogenous causal agent, profit opportunities have a logical problem: if there are no other assumptions, the mere existence of opportunities does not adequately explain entrepreneurial alertness. To address this gap, this study considered samples from mainland China, where entrepreneurial activities are very active currently, to test the role that entrepreneurial alertness is assumed to play in the planned behavior model. The results show that the three dimensions of alertness, individually partly intermediate the influence of entrepreneurial attitude on entrepreneurial intention, the influence of subjective norms on entrepreneurial intention, and that of perceived behavior control on entrepreneurial intention. This article studied the production of entrepreneurial intention by integrating the two patterns of planned behavior and alertness through empirical analysis, and opened up a new field for subsequent research on entrepreneurial intention.
\end{abstract}

Keywords: Entrepreneurial Alertness, Entrepreneurial Intention, Entrepreneurial Attitude, Subjective Norms, Entrepreneurial Behavior Control, Planned Behavior, China.

JEL Classification Code: M10, M13.

\section{Introduction}

Research on entrepreneurial intention in terms of a theoretical framework has rapidly increased recently. However, a rethinking of the role of entrepreneurial intention in research has been proposed (Fayolle \& Liñán, 2014). Based on the theory of planned behavior, many scholars studied the interactions of attitudes, subjective norms, and perceived behavior controls on individual intention (Ajzen, 1991), or developed their own entrepreneurial intention model using different determinants (Shinnar, Giacomin, \& Janssen, 2012; Siu \& Lo, 2013). Many studies supported the theory of planned behavior regarding the influence on entrepreneurial intention (Díaz-García \& Jiménez-Moreno,

1 First Author and Corresponding Author. Ph.D. candidate, ChinaASEAN International College, Dhurakij Pundit University, Bangkok, Thailand [Postal Address: 110/1-4, Prachachuen Rd., Laski, Bangkok 10210, Thailand]. E-mail: sdyclv@163.com

2 Associate Professor, ShanDong YingCai University, JiNan, China.

3 Professor. China-ASEAN International College, Dhurakij Pundit University, Bangkok, Thailand. E-mail: jehome_wang@qq.com
2010; Kolvereid, 2016; Liñán \& Chen, 2009). However, there are also different research findings that suggest that entrepreneurial attitudes do not significantly influence entrepreneurial intention (Siu \& Lo, 2013), Zhang et al. did not find support to show that entrepreneurial attitudes influence entrepreneurial intention (Zhang, Wang, \& Owen, 2015). These findings are quite different from other research (Guerrero, Rialp, \& Urbano, 2008). The other research argued that subjective norms do not affect entrepreneurial intention (Robledo, Arán, Martin-Sanchez, \& Molina, 2015), which is different from the research by Siu and Lo (Siu \& Lo, 2013). With the emergence of several different research conclusions on entrepreneurial intention, this subject warrant further analysis.

Entrepreneurial alertness is a different psychological schema and cognitive framework, which is portrayed by individuals to discover environmental changes (Valliere, 2013). It could also be defined as the ability of individuals to identify opportunities ignored by others, or the perspectives that can make some individuals more aware of the possibilities of change, transformation, opportunities, and 
neglect (Kirzner, 1973; Kirzner, 1979, 1985). As a variable that characterizes an individual's cognitive process for entrepreneurial opportunities, entrepreneurial alertness may be influenced by factors such as individual characteristics, training and experience, social networks, etc. (Tang, Kacmar, \& Busenitz, 2012). Therefore, entrepreneurial alertness may be associated with the variables in the planned behavior model, and this provides another framework to study entrepreneurial intention.

The remainder of the paper is structured as follows. Section 1 presents the literature review, while Section 2 describes the research hypotheses. Section 3 discusses the research design, and Section 4 presents the results. Finally, Section 5 concludes the paper.

\section{Literature Review}

Entrepreneurial intention, which is the state of consciousness of entrepreneurs' direct attention, experience, and action to a business concept (Bird, 1988), is usually defined as the desire of individuals to either own their own business (Crant, 1996), or to start one (Krueger, Reilly, \& Carsrud, 2000). In their study on entrepreneurial intention, many scholars applied the theory of planned behavior as their theoretical basis (Fini, Grimaldi, Marzocchi, \& Sobrero, 2012; Gelderen et al., 2008; Liñán \& Chen, 2009; Rauch \& Hulsink, 2015; Robledo et al., 2015; Souitaris, Zerbinati, \& Al-Laham, 2007; Zhang et al., 2015). According to the entrepreneurial intention model, another extensive study on entrepreneurship was undertaken(Adam \& Fayolle, 2016). Many research studies on entrepreneurial intention supported the theory of planned behavior (Díaz-García \& Jiménez-Moreno, 2010; Kolvereid, 2016; Liñán \& Chen, 2009), and validated the robustness and pertinence of the entrepreneurial intention model, which applied the theory of planned behavior to predict entrepreneurial intention (Kautonen, van Gelderen, \& Fink, 2015). These studies argue that individual's attitude toward entrepreneurship, perceptive behavior control, and subjective norms are antecedent variables of entrepreneurial intention (Miralles, Giones, \& Riverola, 2016; Solesvik, 2013).Some studies partially support the intention model of the theory of planned behavior, which examines the effects of self-employment preferences, subjective norms, and perceived behavioral control on entrepreneurial intention (Kolvereid, 2016). Other studies verify that subjective norms positively affect entrepreneurial intention (Tsai, Chang, \& Peng, 2014), which others argue that individual attitudes and behavioral controls are the most relevant factors in explaining entrepreneurial intention(Liñán, Rodríguez-Cohard, \& Rueda-Cantuche, 2011).
However, some research studies have even different conclusions, which perceived that behavioral control and attitudes affect college students' entrepreneurial intention, while subjective norms do not affect it (Robledo et al., 2015). In addition, some studies depict that American and Turkish students with positive entrepreneurial attitudes expressed low level of entrepreneurial intention (Ozaralli \& Rivenburgh, 2016). The study that obtained samples with a collectivism background found that the entrepreneurial social norms perceived and entrepreneurial self-efficacy have a significant impact on entrepreneurial intention, and that the effect of entrepreneurial attitude on entrepreneurial intention was not significant (Siu \& Lo, 2013). Social norms, control behaviors, and entrepreneurial intention are positively correlated, while attitude has no significant influence on entrepreneurial intention (Zhang et al., 2015). In two components (i.e., beliefs about self-efficacy and controllability) of perceived behavior control (Ajzen, 2002b), self-efficacy was assumed by scholars to be an explanatory variable of entrepreneurial intention (McGee, Peterson, Mueller, \& Sequeira, 2009), and that it positively influences entrepreneurial intention (BarNir, Watson, \& Hutchins, 2011; Mortan, Ripoll, Carvalho, \& Bernal, 2014; Tsai et al., 2014). Further, some scholars believe that entrepreneurial alertness and entrepreneurial self-efficacy are key elements to predict entrepreneurial intention (Hu \& Ye, 2017).

The three dimensions of entrepreneurial alertness include systematically or unsystematically scanning and searching for information in an environment, associating and joining previous irrelevant information, and evaluating and judging business ideas (Tang et al., 2012). These are also the three sequential processes of cognitive development for individuals to recognize opportunities. First, entrepreneurs are alert to scan and search, which makes them continually and unconventionally explore new ideas (Busenitz, 1996). The perceived information constitutes an individual's perceptual information base and provides a concise storage of information in the initial form (Reed, 2012). By perceiving information continuously, the tacit knowledge and explicit knowledge in individuals' knowledge base would be strengthened (Polanyi, 1967). Individuals apply tacit knowledge and explicit knowledge to promote the integration and accumulation of new knowledge to adapt to new situations (Weick, 1996). In this process of information adapting and matching, individuals could directly access business opportunities.

Second, by their own perceived information base, individuals connect and combine information and knowledge to form a whole picture in their minds (Lehrer, 2008). Two or more than two parts of previously unrelated information or ideas may also suddenly combine with each other (Koestler, 1964). Whether the information parts are unusual or 
unexpected, their association makes entrepreneurs change their already existing psychological schema to adapt to the unmatched information (Gaglio \& Katz, 2001). Through information associated or connected, the characteristics of original information may be changed or new information may be generated, wherein individuals may also identify information about entrepreneurial opportunities.

Third, by matching the new information with their own prototype or sample about business opportunities, at some point, the individuals will assess whether the newly conceived information is suitable for their existing cognitive schema (Baron, 2006), and whether there are new opportunities. By evaluating and judging new changes, transformation, or information, individuals will decide whether they are profitable business opportunities (Tang et al., 2012). The three dimensions of entrepreneurial alertness are influenced in sequence. In other words, scanning and searching positively influence association and connection, which in turn positively impact evaluation and judgment at any one stage or three stages in sequence, wherein individuals could recognize entrepreneurial opportunities. Individuals may identify information about entrepreneurial opportunities by factors interacting with each other suddenly. Therefore, entrepreneurial alertness positively affects entrepreneurial intention (Lim, Lee, \& Ramasamy, 2015; Mortan et al., 2014), and is one of the two most important variables to explain entrepreneurial intention (Gelderen et al., 2008). Thus, scanning, searching, association and connection, and evaluation and judgment are the four factors that constitute the optimal factor structure to explain entrepreneurial alertness (Chen \& Liang, 2015).

\section{Research Hypotheses}

Researchers generally believe that attraction of interest drives the entrepreneurial alertness process (Kirzner \& Sautet, 2006). However, opportunities for making profit are considered exogenous causal agents. If no other assumptions exist, then there is a logical question that it is not enough to fully explain the existence of entrepreneurs' alertness only with that opportunity (McCaffrey, 2014). Some scholars have examined the impact of a proactive personality on entrepreneurial alertness (Uy, Chan, Sam, Ho, \& Chernyshenko, 2015). Individuals with a proactive personality often exhibit a positive attitude. Entrepreneurial attitude is an individual's personal positive or negative assessment of being an entrepreneur, including the emotional factor (I love it, it's attractive) and assessable items (have interests) (Liñán \& Chen, 2009). Thus, it can be inferred that there may be a link between entrepreneurial alertness and individual attitudes toward entrepreneurship. Perhaps the positive entrepreneurial attitude enhances individuals' entrepreneurial alertness, thus enabling them to identify more information on opportunities, eventually enhancing their entrepreneurial intention. Since both entrepreneurial alertness and entrepreneurial attitude positively affect entrepreneurial intention, Hypothesis $\mathrm{H} 1$ is put forward and described below.

<Hypothesis 1> Entrepreneurial alertness partly intermediates the influence of entrepreneurial attitude on entrepreneurial intention.

Cognition, emotion, and behavioral tendency are three elements of attitude. Individuals who positively want to become entrepreneurs are more willing to contact, perceive, or accept knowledge and information about entrepreneurship. They will be more willing to actively expand their scope, frequency, and intensity to scan and search for information, and show stronger ability to scan and search information. Thus, individuals can obtain extensive information about entrepreneurship, and identify more information about entrepreneurial opportunities. Accordingly, Hypothesis $\mathrm{H} 1 \mathrm{a}$ is proposed below.

$<$ Hypothesis 1a> Alert scanning and searching partly intermediate the influence of entrepreneurial attitude on entrepreneurial intention.

Individuals who are more positive about becoming entrepreneurs have a positive performance in terms of cognition, emotion, and inclination. The psychological cognition of being an entrepreneur is also more positive for them. Individuals who manage their knowledge and information base that is obtained by scanning and researching, will be more active in implementing information association and connection. Hence, they can obtain more new information and schema, find more new changes and transformations, and identify more new profit-generating opportunities. Accordingly, Hypothesis $1 \mathrm{~b}$ is indicated below.

$<$ Hypothesis $\mathbf{1 b}>$ Alert association and connection partly intermediate the influence of entrepreneurial attitude on entrepreneurial intention.

Individuals who are more active toward becoming entrepreneurs have a more positive psychological tendency to identify entrepreneurial opportunities. They are more positive in evaluating entrepreneurs, more willing to take risks, and have more expectations to realize entrepreneurial value. Hence, under the same information in terms of content and quantity, in their stage of evaluation and 
judgment, these individuals can identify more information on profit-generating opportunities, which were either ignored or not considered valuable by others. They express greater ability in evaluation and judgment, and could obtain more information on opportunities that generate profit. Accordingly, Hypothesis $1 \mathrm{c}$ is stated below.

<Hypothesis 1c> Evaluation and judgment partly intermediate the influence of entrepreneurial attitude on entrepreneurial intention.

In the study on entrepreneurship, subjective norms refer to individuals' perception of acquaintances, including family members, friends, or significant others to approve or disapprove their decision to become an entrepreneur (Liñán, 2008). With influence, these acquaintances may affect individuals' entrepreneurial motivation, or could also provide support and resources needed by individuals, and enhance their attractiveness to individuals or perceived behavior control (Liñán \& Santos, 2007). Certain political and institutional settings are more conducive to the prevalence of entrepreneurship (Minniti, 2004), and more influential to members in microenvironments. Thus, individuals' subjective norms are influenced. Environmental forces (or munificence) are closely related to alertness (Tang, 2008a). Perhaps, the positive influence of environmental factors enhances individuals' entrepreneurial alertness, which, in turn enhances individuals' entrepreneurial intention. Therefore, Hypothesis 2 is assumed, as follows.

$<$ Hypothesis 2> Entrepreneurial alertness partly intermediates the influence of subjective norms on entrepreneurial intention.

The higher the level of approval offered to individuals to become entrepreneurs by the acquaintances who are involved in individuals' subjective norms, the more is their ability to help individuals extend their vision and scope of scanning and searching, and association and connection, and the more likely they are to provide standards or help for individual evaluations and judgments. On the other hand, support from acquaintances may help alleviate the mental stress of entrepreneurs, make individuals' behavior of scanning and searching more active, enable individuals to develop associations and connections, and evaluate and judge in a better mental state, and show more powerful relevant ability. Therefore, three hypotheses are proposed below.

$<$ Hypothesis 2a> Alert scanning and searching partly intermediate the influence of subjective norms on entrepreneurial intention.
$<$ Hypothesis $\mathbf{2}$ b $>$ Alert association and connection partly intermediate the influence of subjective norms on entrepreneurial intention.

$<$ Hypothesis 2c> Evaluation and judgment partly intermediate the influence of subjective norms on entrepreneurial intention.

Perceived control over the performance of a behavior comprises separable components that reflect beliefs about self-efficacy and controllability (Ajzen, 2002b). The first factor is related to confidence in the ability to fulfill completely; second, and that reflects self-efficacy beliefs; the factor reflects control belief, which is the controllability of behavior. Self-efficacy and controllability can reflect internal factors as well as external factors separately (Ajzen, 2002b). Entrepreneurial alertness is influenced by individual temperament, training and experience, and social network (Tang et al., 2012). Individual characteristics, including human capital (previous knowledge, work experience), social capital (structured, relational), and social competence (social cognition, social adaptation, expressiveness, impression management) all affect an individual's entrepreneurial alertness (Tang, 2008b). In other words, individuals' internal character, external training and experience, and social network affect their entrepreneurial alertness. Therefore, Hypothesis 3 is suggested below.

<Hypothesis 3> Entrepreneurial alertness partly intermediates the influence of entrepreneurial behavior control on entrepreneurial intention.

Perceived behavioral control is defined as the perception of the difficult degree to become an entrepreneur. It is the perception about an individual's ability to implement an enterprise's creation behavior (Liñán \& Chen, 2009), similar to the concept of self-efficacy (Bandura, 1997). This refers to not only the feeling of competence, but also the sense of control over the behavior (Ajzen, 2002a). Individuals with high levels of perceived behavior control may perform better in alert scanning and searching for information on opportunities, associating and connecting present information, and evaluating and judging profit opportunities' information. Accordingly, three hypotheses are stated below.

<Hypothesis 3a> Alert scanning and research partly intermediate the influence of entrepreneurial behavior control on entrepreneurial intention.

$<$ Hypothesis $\mathbf{3 b}>$ Alert association and connection partly intermediate the influence of entrepreneurial behavior control on entrepreneurial intention. 
$<$ Hypothesis 3c> Evaluating and judging partly intermediate the influence of entrepreneurial behavior control on entrepreneurial intention.

To sum up, the conceptual framework of this study is depicted by Figure 1.

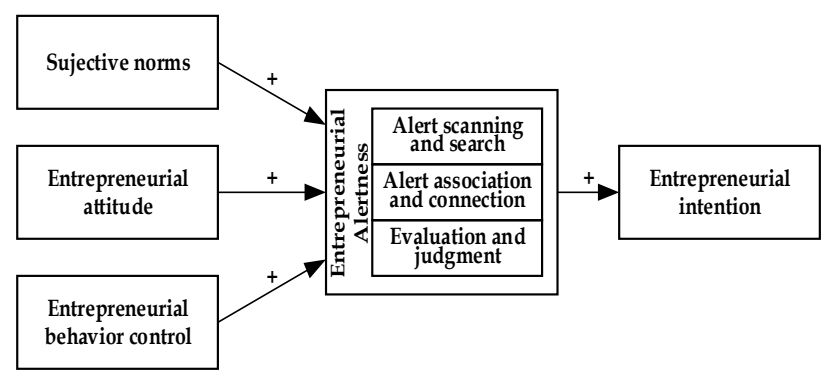

Figure 1. Research Framework

\section{Research Design}

\subsection{Research Sample}

The research samples are obtained from 24 of the 32 provincial-level regions of mainland China, which include 543 entrepreneurs or potential entrepreneurs. In total, 451 valid questionnaires were received. The respondents comprised 185 males and 266 females. Six respondents were aged 56 years and above, 14 were aged 46 to 55 years, 45 aged 36 to 45 years, 194 aged 26 to 35 years, 191 aged 18 to 25 years, and 1 respondent who was younger than 18 years. In terms of educational experience, the respondents comprised 1 doctor, 28 postgraduates, 298 undergraduates, 108 with junior college educational experience, 13 with high school educational experience, and 3 who were junior high school and below. About 262 people did not have any entrepreneurial experience, while 140 have a single entrepreneurial experience, 39 have two such experiences, 7 have three experiences, 2 have five times, and 1 has six experiences.

\subsection{Variable Measurement}

The Likert 5-point score was used, from 1 (totally disagree) to 5 (completely agree).

Entrepreneurial alertness: In this paper, we use the entrepreneurial alertness scale with 13 items, as developed by Tang et al. (Tang et al., 2012). The Cronbach's Alpha values of the three subscales (scanning and search have six items, association and connection have three, and evaluation and judgment have four items) were reported as $0.91,0.94$, and 0.90 , respectively.

Entrepreneurial intention: This article uses the entrepreneurial intention scale with six items, which was developed by Linan and Chen (Liñán \& Chen, 2009; Liñán et al., 2011). The Cronbach's Alpha value was 0.943. Ilouga, Phipps, and others also used the scale to measure entrepreneurial intention (Ilouga, Mouloungni, \& Sahut, 2014; Phipps \& Prieto, 2015; Phipps, Prieto, \& Kungu, 2015).

Entrepreneurial attitude, subjective norms, and entrepreneurial behavior control: The study employed the entrepreneurial attitude scale that was developed by Linan and Chen (Liñán \& Chen, 2009), including five items. The Cronbach's Alpha value that Linan and Chen reported was 0.897 . The study also employed the subjective norms scale that was developed by Linan and Chen (Liñán \& Chen, 2009), including three items. The Cronbach's Alpha value reported was 0.773. The research employed the entrepreneurial behavior control scale that was developed by Linan and Chen (Liñán \& Chen, 2009), including six items. The Cronbach's Alpha value that was reported by Linan and Chen was 0.885 .

Control variables: Existing studies suggest that there are significant differences in the entrepreneurial intention among different gender roles (BarNir et al., 2011; Nwankwo, Kanu, Marire, Balogun, \& Uhiara, 2012), and that gender has an impact on entrepreneurial intention and entrepreneurial motivation (Raaj \& Shri, 2015), and also on entrepreneurial self-efficacy (Wilson, Kickul, \& Marlino, 2007). Age has a negative influence on perception opportunity and entrepreneurial intention (Tsai, Chang, \& Peng, 2016), and also affects individuals' entrepreneurial alertness (Chen \& Liang, 2015). Demographic differences affect individuals' entrepreneurial self-efficacy, entrepreneurial alertness, and entrepreneurial intention (Hu \& Ye, 2017). Therefore, this study controls for the two variables of age and gender. Education can affect individuals' cognitive and cognitive abilities. Entrepreneurial education can increase the entrepreneurial attitude of potential and new entrepreneurs (Liñán et al., 2011), and an education program can inspire entrepreneurial intention, leading to the creation of new small businesses (Bolin \& Fountain, 2014). Therefore, this study also controls for the variable of education experience. The entrepreneurial experience is related to the optimism of entrepreneurs (Ucbasaran, Westhead, Wright, \& Flores, 2010), entrepreneurs' development behavior, identity aspiration (Farmer, Yao, \& Kung-Mcintyre, 2011), and entrepreneurial alertness (Li, Wang, \& Liang, 2015). Therefore, this study also controls for entrepreneurial experience.

\section{Research Results}

\subsection{Reliability and Validity Analysis}

The reliability test was conducted using Cronbach's Alpha, and the values were found to be 0.948 for all 33 items. Each 
variable's Cronbach's Alpha value is as follows: entrepreneurial attitude (five items) 0.829 , subjective norms (three items) 0.76 , perceived behavior control (six items) 0.896 , alert scanning and searching (six items) 0.851 , alert association and connection (three items) 0.842, evaluation and judgment (four items) 0.827 , and entrepreneurial intention (six items) 0.922. The discriminant validity between variables was tested using confirmatory factor analysis. The model was analyzed by using the Mplus statistical analysis software to investigate the fitting degree of the model, found that the model chi-square value $\chi^{2}$ is $1220.125(\mathrm{P}<0.05), \mathrm{df}=474, \chi^{2} / \mathrm{df}=2.57$. This expresses that the degree of the model has a simple adaptation, $\mathrm{CFI}=.916>0.9$ $\mathrm{TLI}=0.906>0.9, \mathrm{RMSEA}=0.059<0.08$, and SRMR $=0.046<0.05$, suggesting that the model fitting effect is good. The results also suggest that the discriminant validity between these seven variables is good.

\subsection{Descriptive Statistics and Correlation Analysis}

The mean, standard deviation, and correlation coefficient of each variable or dimension are shown in Table 1. (EDE is education experience, ENE is entrepreneurial experience, EA is entrepreneurial attitude, SN denotes subjective norms, EBC is entrepreneurial behavior control, ASS is alert scanning and search, AAC is alert association and connection, EJ is evaluation and judgment, and $\mathrm{EI}$ is entrepreneurial intention.)

As shown in Table 1, gender, age, and entrepreneurial experience are related to multiple variables or dimensions. This supports the choice of control variables in this article. A correlation exists between entrepreneurial attitude, subjective norms, behavioral control, the three dimensions of entrepreneurial alertness, and entrepreneurial intention. This provides initial support for the hypotheses of this study.

\subsection{Results of Hypotheses Testing}

Using Amos statistical software for testing the hypotheses, the path analysis was carried out using the structural equation model, and the results are shown in Figure 2.

Table 1. Descriptive statistical analysis

\begin{tabular}{|c|c|c|c|c|c|c|c|c|c|c|c|c|}
\hline & $\mathbf{M}$ & SD & Gender & Age & EDE & ENE & EA & SN & EBC & ASS & AAC & EJ \\
\hline Gender & .410 & .492 & 1 & & & & & & & & & \\
\hline Age & 2.77 & .852 & $.110^{*}$ & & & & & & & & & \\
\hline EDE & 3.75 & .651 & $-.150^{* \pi}$ & $-.134^{\text {** }}$ & & & & & & & & \\
\hline ENE & .570 & .818 & $.195^{* \star}$ & $.283^{* *}$ & -.034 & & & & & & & \\
\hline EA & 3.876 & .663 & .090 & .025 & -.090 & .060 & & & & & & \\
\hline SN & 3.707 & .632 & -.080 & -.046 & -.047 & -.068 & $.452^{\text {** }}$ & & & & & \\
\hline EBC & 2.938 & .765 & $.234^{* *}$ & $.203^{* *}$ & -.065 & $.236^{* *}$ & $.422^{\star *}$ & $.325^{* k}$ & & & & \\
\hline ASS & 3.652 & .616 & $.190^{* \pi}$ & .092 & -.008 & $.174^{* *}$ & $.415^{\pi x}$ & $.307^{* \pi}$ & $.600^{* \pi}$ & & & \\
\hline AAC & 3.330 & .689 & $.154^{* \pi}$ & $.141^{* *}$ & -.017 & $.198^{* *}$ & $.346^{* *}$ & $.230^{* *}$ & $.578^{* *}$ & $.635^{* *}$ & & \\
\hline EJ & 3.281 & .631 & $.221^{\text {xतx }}$ & $.132^{* \pi}$ & -.027 & $.186^{* \pi}$ & $.403^{\text {xt }}$ & $.299^{* x}$ & $.666^{\text {** }}$ & $.616^{\pi x}$ & $.713^{\text {nxt }}$ & \\
\hline $\mathrm{El}$ & 3.502 & .822 & $.256^{* *}$ & $.141^{* *}$ & -.073 & $.123^{* k}$ & $.485^{* *}$ & $.303^{* *}$ & $.600^{* *}$ & $.518^{* *}$ & $.413^{* *}$ & $.594^{*}$ \\
\hline
\end{tabular}

* indicates a significant correlation at the 0.05 level (bilateral)

** indicates a significant correlation at the 0.01 level (bilateral)

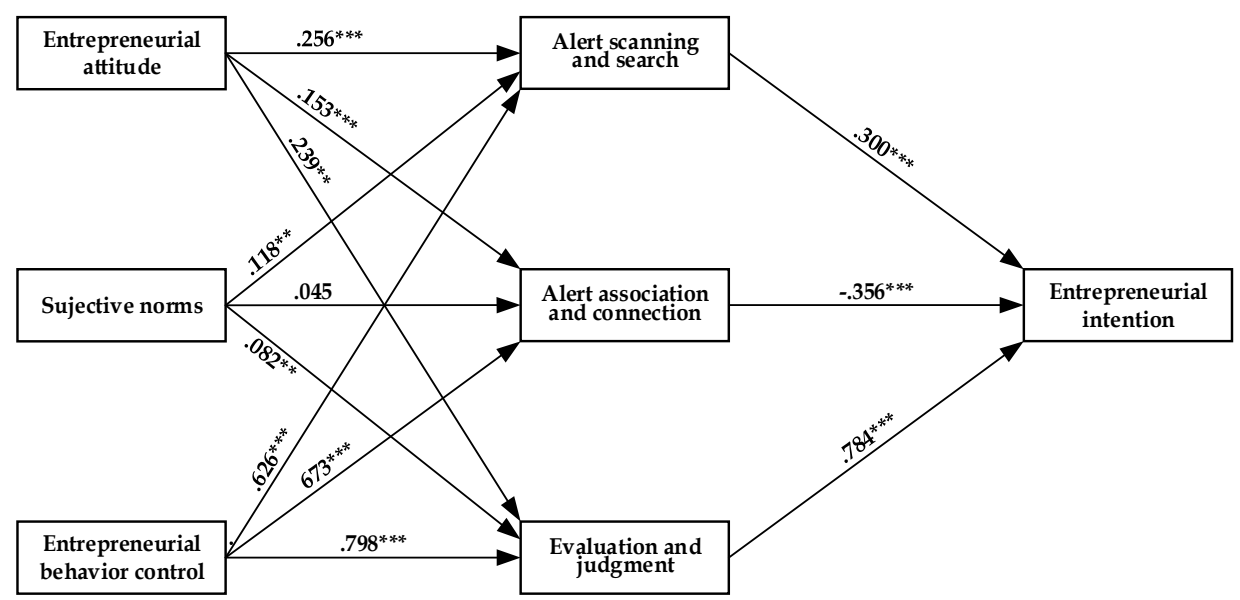

Figure 2. Path analysis diagram 
Among the three dimensions of entrepreneurial alertness, alert scanning and searching, and evaluation and judgment have a significant positive influence on entrepreneurial intention, with a coefficient of $0.300(P<0.001)$ and 0.784 $(P<0.001)$, respectively. Alert association and connection is negatively and significantly associated to entrepreneurial intention, and its coefficient is -0.356 $(\mathrm{P}<0.001)$. Entrepreneurial attitude has significant positive influences on alert scanning and searching, alert association and connection, and evaluation and judgment, with its direct influence degrees being $0.256(P<0.001), 0.153(P<0.01)$, and $0.239(P<0.001)$, respectively. Thus, hypotheses $1 \mathrm{a}, 1 \mathrm{~b}$ and $1 \mathrm{c}$ are verified.

Alert scanning and searching, alert association and connection, and evaluation and judgment partly intermediate the influence of entrepreneurial attitude on entrepreneurial intention respectively, that is, entrepreneurial alertness partly intermediates the influence of entrepreneurial attitude on entrepreneurial intention, which supports Hypothesis 1. Subjective norms have a significant positive influence on alert scanning and searching, and evaluation and judgment. The coefficients are $0.118(P<0.05)$ and $0.082(P<0.05)$, respectively, and thus, Hypotheses $2 \mathrm{a}$ and $2 \mathrm{c}$ are supported. The effect of alert association and connection is not significant, and the coefficient is $0.045(\mathrm{P}>0.05)$. Therefore, Hypothesis $2 b$ is not supported, but Hypothesis 2 is supported partly. Entrepreneurial behavior control has a significant positive influence on alert scanning and searching, association and connection, and evaluation and judgment, with the correlation coefficients being 0.626 $(P<0.001), 0.673 \quad(P<0.001)$, and $0.001 \quad(P<0.001)$, thus supporting Hypotheses $3 \mathrm{a}, 3 \mathrm{~b}$, and $3 \mathrm{c}$. Therefore, alert scanning and searching, alert association and connection, and evaluation and judgment partly intermediate the influence of entrepreneurial behavior control on entrepreneurial intention, that is, entrepreneurial alertness partly intermediates the influence of entrepreneurial behavior control on entrepreneurial intention, thus supporting Hypothesis 3.

\section{Conclusions and Limitations}

The level of individual alertness is associated with the number and quality of opportunities that individuals can identify. Identifying opportunities leads to the creation of entrepreneurial intention. This study verifies that individuals' attitudes toward entrepreneurship not only directly affect the intention, but by influencing entrepreneurial alertness, they also affect individuals' find for opportunity, eventually influencing individuals' entrepreneurial intention. The implication of this finding is that found the effects of entrepreneurial attitude on entrepreneurial intention, not merely a single individual "emotional path", but at the same time there is a "interest path" by means of opportunities find. The results also further enlighten the theory of planned behavior, and state that attitude is not simply an "attitude" in relation to the influence of intention. The study also verifies the influence of entrepreneurial behavior control (including control belief and self-efficacy belief) on entrepreneurial intention, and also both the direct and indirect effects through entrepreneurial alertness. This discovery also further elucidates the theory of planned behavior, implying that in the relationship between perceived behavior control and intention, faith plays a role not in the pure faith.

This study verifies that in the relationship between subjective norms for entrepreneurial intention, the two dimensions of alert scanning and searching, and evaluation and judgment play an intermediary role. The research also shows that subjective norms not only directly affect entrepreneurial intention, but by influencing individuals' alert behavior (alert scanning and searching, as well as evaluation and judgment behaviors), also indirectly affect entrepreneurial intention. In addition, the relationship between subjective norms and alert association and connection was not found to be significant. This is probably because association and connection is an individual internal cognitive ability, formed in many ways by various factors (for example, training, experience, etc.) over a long period, as a kind of relatively stable psychological mode, less affected by the external factors (subjective norms).

In this study, entrepreneurial alertness is introduced into the planning behavior model, which enriches and expands the existing literature on entrepreneurial intention. At the same time, the study finds a link between the planned behavior pattern and the alert mode of the research on entrepreneurial intention, which shows the feasibility of the integration, and identifies a new path for studying entrepreneurial intention.

However, there are several limitations in this research. Due to the limitations of the conditions, the sample selection and sampling are not perfect. The research conclusions also need to be supported by more extensive literature.

\section{References}

Adam, A.-F., \& Fayolle, A. (2016). Can implementation intention help to bridge the intention-behaviour gap in the entrepreneurial process? An experimental approach. The International Journal of Entrepreneurship and Innovation, 17(2), 80-88. 
Ajzen, I. (1991). The theory of planned behavior. Organizational Behavior and Human Decision Processes, 50(2), 179-211.

Ajzen, I. (2002a). Perceived Behavioral Control, SelfEfficacy, Locus of Control, and the Theory of Planned Behavior. Journal of Applied Social Psychology, 32(4), 665-683.

Ajzen, I. (2002b). Residual effects of past on later behavior: Habituation and research action perspectives. Personality and Social Psychology Review, 6(2), 107-122.

Bandura, A. (1997). Self-efficacy: The Exercise of Control. New York: W.H. Freeman and Company.

BarNir, A., Watson, W. E., \& Hutchins, H. M. (2011). Mediation and moderated mediation in the relationship among role models, self-efficacy, entrepreneurial career intention, and gender. Journal of Applied Social Psychology, 41(2), 270-297.

Baron, R. A. (2006). Opportunity recognition as pattern recognition: How entreoreneurs 'Connect the dots' to identify new business opportunities. Academy of Management Perspectives, 20(1), 104-119.

Bird, B. (1988). Implementing entrepreneurial ideas: The case for intention. Academy of Management Review, 13(3), 442-453.

Bolin, S., \& Fountain, P. D. P. (2014). Do entrepreneurial camp programs influence entrepreneurial intention of participants?: A proposed study of an experiential learning approach to creating new entrepreneurs. Proceedings of the Annual Meeting of the Association of Collegiate Marketing Educators (pp.83-99), Dallas, USA: AMACME.

Busenitz, L. W. (1996). Research on entrepreneurial alertness. Journal of Small Business Management, 34(4), 35-44.

Chen, C.-C., \& Liang, C. (2015). Job statuses of agrirural workers on their entrepreneurial alertness. International Journal of Business and Social Science, 6(8), 80-88.

Crant, J. M. (1996). The proactive personality scale as a predictor of entrepreneurial intention. Journal of small business management, 34(3), 42-49.

Díaz-García, M. C., \& Jiménez-Moreno, J. (2010). Entrepreneurial intention: The role of gender. International Entrepreneurship and Management Journal, 6(3), 261-283.

Farmer, S. M., Yao, X., \& Kung-Mcintyre, K. (2011). The behavioral impact of entrepreneur identity aspiration and prior entrepreneurial experience. Entrepreneurship Theory and Practice, 35(2), 245273.
Fayolle, A., \& Liñán, F. (2014). The future of research on entrepreneurial intentions. Journal of Business Research, 67(5), 663-666.

Fini, R., Grimaldi, R., Marzocchi, G. L., \& Sobrero, M. (2012) The Determinants of Corporate Entrepreneurial Intention Within Small and Newly Established Firms. Entrepreneurship Theory and Practice, 36(2), 387414.

Gaglio, C. M., \& Katz, J. A. (2001). The Psychological Basis of Opportunity Identification: Entrepreneurial Alertness. Small Business Economics, 16(2), 95-111.

Gelderen, M. V., Brand, M., Praag, M. V., Bodewes, W., Poutsma, E., \& Gils, A. V. (2008). Explaining entrepreneurial intentions by means of the theory of planned behaviour. Career Development International, 13(6), 538-559.

Guerrero, M., Rialp, J., \& Urbano, D. (2008). The impact of desirability and feasibility on entrepreneurial intentions: A structural equation model. International Entrepreneurship and Management Journal, 4(1), 35-50.

Hu, R., \& Ye, Y. (2017). Do entrepreneurial alertness and self-efficacy predict Chinese sports major students' entrepreneurial intention?. Social Behavior \& Personality: An International Journal, 45(7), 11871196.

llouga, S. N., Mouloungni, A. C. N., \& Sahut, J. M. (2014). Entrepreneurial intention and career choices: The role of volition. Small Business Economics, 42(4), 717-728.

Kautonen, T., van Gelderen, M., \& Fink, M. (2015). Robustness of the Theory of Planned Behavior in Predicting Entrepreneurial Intentions and Actions. Entrepreneurship Theory and Practice, 39(3), 655674.

Kirzner, I. M. (1973). Competition and Entrepreneurship. Chicago, IL: University of Chicago Press.

Kirzner, I. M. (1979). Perception, Opportunity, and Profit: Studies in the Theory of Entrepreneurship. Chicago: The University of Chicago Press.

Kirzner, I. M. (1985). Discovery and the Capitalist Process. Chicago, IL: University of Chicago Press.

Kirzner, I. M., \& Sautet, F. (2006). The Nature and Role of Entrepreneurship in Markets: Implications for Policy. In Mercatus Policy Series, Policy Primer No. 4, June 2006, Mercatus Center, George Mason University.

Koestler, A. (1964). The Act of Creation: A Study of Conscious and Unconscious Processes in Humor, Scientific Discovery and Art. New York: The Macmillan Company.

Kolvereid, L. (2016). Preference for self-employment: Prediction of new business start-up intentions and 
efforts. The International Journal of Entrepreneurship and Innovation, 17(2), 100-109.

Krueger, N. F., Reilly, M. D., \& Carsrud, A. L. (2000). Competing models of entrepreneurial intentions. Journal of Business Venturing, 15(5), 411-432.

Lehrer, J. (2008). The Eureka Hunt: Why do good ideas come to us when they do?. The New Yorker, (July 28), pp.40-45.

Liñán, F. (2008). Skill and value perceptions: How do they affect entrepreneurial intentions?. International Entrepreneurship \& Management Journal, 4(3), 257272.

Liñán, F., \& Chen, Y.-W. (2009). Development and crosscultural application of a specific instrument to measure entrepreneurial intentions. Entrepreneurship Theory and Practice, 33(3), 593617.

Liñán, F., Rodríguez-Cohard, J. C., \& Rueda-Cantuche, J. M. (2011). Factors affecting entrepreneurial intention levels: A role for education. International Entrepreneurship and Management Journal, 7(2), 195-218.

Liñán, F., \& Santos, F. J. (2007). Does Social Capital Affect Entrepreneurial Intentions?. International Advances in Economic Research, 13(4), 443-453.

Li, Y., Wang, P., \& Liang, Y.-J. (2015). Influence of entrepreneurial experience, alertness, and prior knowledge on opportunity recognition. Social Behavior and Personality: An international journal, 43(9), 1575-1583.

Lim, W., Lee, Y. L., \& Ramasamy, R. (2015). Personality, prior knowledge, social capital and entrepreneurial intentions: Entrepreneurial alertness as mediator. Global Journal of Business and Social Science Review, 1(2), 538-548.

McCaffrey, M. (2014). On the Theory of Entrepreneurial Incentives and Alertness. Entrepreneurship Theory and Practice, 38(4), 891-911.

McGee, J. E., Peterson, M., Mueller, S. L., \& Sequeira, J. M. (2009). Entrepreneurial self-efficacy: Refining the measure. Entrepreneurship Theory and Practice, 33(4), 965-988.

Minniti, M. (2004). Entrepreneurial alertness and asymmetric information in a spin-glass model. Journal of Business Venturing, 19(5), 637-658.

Miralles, F., Giones, F., \& Riverola, C. (2016). Evaluating the impact of prior experience in entrepreneurial intention. International Entrepreneurship and Management Journal, 12(3), 791-813.

Mortan, R. A., Ripoll, P., Carvalho, C., \& Bernal, M. C. (2014). Effects of emotional intelligence on entrepreneurial intention and self-efficacy. Journal of Work and Organizational Psychology, 30(3), 97-104.

Nwankwo, B. E., Kanu, G. C., Marire, M. I., Balogun, S. K., \& Uhiara, A. C. (2012). Gender-role orientation and self-efficacy as correlates of entrepreneurial intention European Journal of Business \& Social Sciences, 1(6), 9-26.

Ozaralli, N., \& Rivenburgh, N. K. (2016). Entrepreneurial intention: antecedents to entrepreneurial behavior in the USA and Turkey. Journal of Global Entrepreneurship Research, 6(1), 1-32.

Phipps, S. T. A., \& Prieto, L. C. (2015). Politicking and entrepreneurship: Determining the critical political skill demensions for high entrepreneurial intentions. Academy of Entrepreneurship Journal, 21(2), 73-86.

Phipps, S. T. A., Prieto, L. C., \& Kungu, K. K. (2015). Exploring the influence of creativity and polotical skill on entrepreneurial intentions among men and women: A comparisons between Kenya and the United States. International Journal of Entrepreneurship, 19(1), 179-194.

Polanyi, M. (1967). The Tacit Dimension. Garden City, NY: Anchor

Raaj, V. G., \& Shri, M. (2015). Impact of gender on entrepreneurial intention \& motivation among MBA students. Sona Global Management Review, 9(4), 129-140.

Rauch, A., \& Hulsink, W. (2015). Putting entrepreneurship education where the intention to act lies: An investigation into the impact of entrepreneurship education on entrepreneurial behavior. Academy of Management Learning \& Education, 14(2), 187-204.

Reed, S. K. (2012). Cognition: Theories and Applications(9th ed). California: Wadsworth Pub Co.

Robledo, J. L. R., Arán, M. V., Martin-Sanchez, V., \& Molina, M. Á. R. (2015). The moderating role of gender on entrepreneurial intentions: A TPB perspective. Intangible Capital, 11(1), 92-117.

Shinnar, R. S., Giacomin, O., \& Janssen, F. (2012). Entrepreneurial perceptions and intentions: The role of gender and culture. Entrepreneurship Theory and Practice, 36(3), 465-493.

Siu, W. s., \& Lo, E. S. c. (2013). Cultural contingency in the cognitive model of entrepreneurial intention. Entrepreneurship Theory and Practice, 37(2), 147173.

Solesvik, M. Z. (2013). Entrepreneurial motivations and intentions: investigating the role of education major. Education + Training, 55(3), 253-271.

Souitaris, V., Zerbinati, S., \& Al-Laham, A. (2007). Do entrepreneurship programmes raise entrepreneurial intention of science and engineering students?. The 
effect of learning, inspiration and resources. Journal of Business Venturing, 22(4), 566-591.

Tang, J. (2008a). Environmental munificence for entrepreneurs: Entrepreneurial alertness and commitment. International Journal of Entrepreneurial Behavior \& Research, 14(3), 128-151.

Tang, J. (2008b). Exploring the antecedents of entrepreneurial alertness: Interactions between individual and environmental characteristics. Proceedings of the Conference of United States Association for Small Business and Entrepreneurship. (pp. 1416-1436). San Antonio, TX: USASBE.

Tang, J., Kacmar, K. M., \& Busenitz, L. (2012). Entrepreneurial alertness in the pursuit of new opportunities. Journal of Business Venturing, 27(1), 77-94.

Tsai, K.-H., Chang, H.-C., \& Peng, C.-Y. (2014). Extending the link between entrepreneurial self-efficacy and intention: A moderated mediation model. International Entrepreneurship and Management Journal, 12(2), 445-463.

Tsai, K.-H., Chang, H.-C., \& Peng, C.-Y. (2016). Refining the linkage between perceived capability and entrepreneurial intention: Roles of perceived opportunity, fear of failure, and gender. International
Entrepreneurship and Management Journal, 12(4), 1127-1145.

Ucbasaran, D., Westhead, P., Wright, M., \& Flores, M. (2010). The nature of entrepreneurial experience, business failure and comparative optimism. Journal of Business Venturing, 25(6), 541-555.

Uy, M. A., Chan, K.-Y., Sam, Y. L., Ho, M.-H. R., \& Chernyshenko, O. S. (2015). Proactivity, adaptability and boundaryless career attitudes: The mediating role of entrepreneurial alertness. Journal of Vocational Behavior, 86, 115-123.

Valliere, D. (2013). Entrepreneurial alertness and paying attention. Journal of Enterprising Culture, 21(1), 1-17.

Weick, K. E. (1996). Drop Your Tools: An Allegory for Organizational Studies. Administrative Science Quarterly, 41(2), 301-313.

Wilson, F., Kickul, J., \& Marlino, D. (2007). Gender, entrepreneurial self-efficacy, and entrepreneurial career intentions: Implications for entrepreneurship education. Entrepreneurship Theory and Practice, 31(3), 387-406.

Zhang, P., Wang, D. D., \& Owen, C. L. (2015). A study of entrepreneurial intention of university students. Entrepreneurship Research Journal, 5(1), 61-82. 